\title{
Dipeptidyl peptidase 4 inhibitors in routine clinical practice: experiences from a Scottish teaching hospital
}

\author{
AMY L BROWN', CHRISTOPHER R SAINSBURY', CARL FENELON², ALEXANDER B MULLEN³, \\ GREGORY C JONES'
}

\begin{abstract}
Aims: This study aimed to assess the effect of dipeptidyl peptidase 4 inhibitors (DPP4i) on glycaemia and weight control and review adherence to renal dosing guidance in routine clinical practice.

Methods: A retrospective review of type 2 diabetes patients prescribed a DPP4 $i$ was undertaken in a general hospital. Date, type and dose of DPP4i, $\mathrm{HbA}_{1 \mathrm{c}}$, weight and renal function were recorded at initiation of DPP4i therapy and at the first follow-up appointment at least 3 months later.

Results: Between March 2008 and June 2012, 335 patients were initiated on DPP4i therapy of whom 263 were eligible for study inclusion (baseline median $\mathrm{HbA}_{1 \mathrm{c}} 73$ $\mathrm{mmol} / \mathrm{mol}$ (IQR 65-83), median weight $90.8 \mathrm{~kg}$ (IQR 79.7104 ), approximately $74.8 \%$ with eGFR $>50 \mathrm{ml} / \mathrm{min} / 1.73 \mathrm{~m}^{2}$ ). Sitagliptin $100 \mathrm{mg}$ daily was the most commonly prescribed DPP4i (90.5\%). Median time between DPP4i initiation and follow-up was 189 days (IQR 140-239). At follow-up there was a reduction in $\mathrm{HbA}_{1 \mathrm{c}}$ (median -8.5 $\mathrm{mmol} / \mathrm{mol} ; 95 \% \mathrm{Cl}-10,-6.5 ; \mathrm{p}<0.005)$ and body weight (median -0.45kg; 95\% Cl-1.15, -0.25, p0.033). At initiation the dose of DPP4i was appropriate for $87.7 \%$ of patients. Conclusions: DPP4i are effective in reducing $\mathrm{HbA}_{1 c}$ and body weight in routine specialist secondary care. Inappropriate prescribing in $70 \%$ of patients with eGFR $<50 \mathrm{ml} /$ $\mathrm{min} / 1.73 \mathrm{~m}^{2}$ prompted a review of prescribing practice.

Br J Diabetes Vasc Dis 2014;14:134-137
\end{abstract}

Key words: Dipeptidyl peptidase 4 inhibitors, glycaemic control, type 2 diabetes mellitus, renal dose adjustment, weight control

\footnotetext{
Gartnavel General Hospital, Glasgow, G12 OYN, UK

Glasgow Royal Infirmary, Glasgow, G4 OSF, UK

Strathclyde Institute of Pharmacy \& Biomedical Sciences, Glasgow, G4 ORE, UK
}

Address for correspondence: Miss Amy Brown Pharmacy Department, Gartnavel General Hospital, 1053 Great Western Road, Glasgow, G12 OYN, UK

Tel: +44 (0)1412113322

E-mail: Amy.Brown@ggc.scot.nhs.uk

http://dx.doi.org/10.15277/bjdvd.2014.029

$\begin{array}{ll}\text { Abbreviations and acronyms } \\ \text { CI } & \text { confidence interval } \\ \text { DPP4i } & \text { dipeptidyl peptidase 4 inhibitor } \\ \text { eGFR } & \text { estimated glomerular filtration rate } \\ \text { GLP1 } & \text { glucose-like peptide 1 } \\ \text { GIP } & \text { glucose-dependent insulinotropic peptide } \\ \text { HbA } 1 \text { c } & \text { haemoglobin A1C } \\ \text { NHS } & \text { National Health Service } \\ \text { NICE } & \text { National Institute for Health and Care Excellence } \\ \text { SPC } & \text { summary of product characteristics } \\ \text { SIGN } & \text { Scottish Intercollegiate Guidelines Network }\end{array}$

\section{Introduction}

DPP4i were first introduced into the UK in 2009. They inhibit the action of the principal enzyme involved in the rapid degradation and inactivation of endogenous GLP1, extending its physiological action by up to three-fold. ${ }^{1}$ They also inhibit the degradation of GIP, although its role in the treatment of type 2 diabetes is limited due to an observed down regulation in GIP receptors. ${ }^{2}$ Meta-analyses suggest that DPP4i may reduce $\mathrm{HbA}_{1 \mathrm{c}}$ by $6.6-8.7 \mathrm{mmol} / \mathrm{mol}$ and are effective in reducing $\mathrm{HbA}_{1 \mathrm{c}}$ in comparison to placebo when used as mono-, dual- or triple therapy. ${ }^{3-6}$ The DPP4i class is generally well tolerated clinically and exhibits an overall "weight neutral" effect. ${ }^{4}$

SIGN and NICE guidelines currently recommend DPP4i following or in place of a sulphonylurea for type 2 diabetes in NHS Scotland where metformin alone has failed to achieve glycaemic targets or is not tolerated. Treatment should be continued only if a successful glycaemic response is observed at 3-6 months ( $>5.5 \mathrm{mmol} / \mathrm{mol}$ reduction in $\left.\mathrm{HbA}_{1 \mathrm{c}}\right)^{3,7}$

Clinical trial evidence for glycaemic and weight effects of DPP4i are readily available, but there is a lack of observational data pertaining to the "real-life" practical use of these drugs and their effect on glycaemic and weight control. This study assessed the impact of these drugs on glycaemic control and weight of patients attending the Diabetes Centre, Gartnavel General Hospital, Glasgow, UK.

Four DPP4i were available in the UK at the time research was conducted (linagliptin, saxagliptin, sitagliptin and vildagliptin), with the latter three requiring dosage adjustment in renal impairment according to manufacturer prescribing guidance. This study aimed to assess the appropriateness of the dose prescribed in terms of renal function. Alogliptin has since become available but will not be discussed in the context of this research. 
Table 1 Characteristics of study population*

\begin{tabular}{lc}
\hline Characteristic & \multicolumn{1}{l}{ Value } \\
Age (years) & $59 \pm 12.3(23-87)$ \\
Sex male \% & 55.5 \\
Concomitant glucose lowering therapy $(\%)^{*}$ \\
Metformin & $219(83)$ \\
Sulphonylurea & $158(59.9)$ \\
Thiazolidinedione & $56(21.2)$ \\
Insulin & $40(15.2)$ \\
Others & $3(1.1)$ \\
Number of glucose lowering therapies at point of DPP4i initiation (\%)* & $5(1.9)$ \\
No drugs & $69(26.2)$ \\
Single drug therapy & $166(62.9)$ \\
Dual drug therapy & $24(9.1)$ \\
Triple drug therapy &
\end{tabular}

\section{Methods}

Ethics and data protection approval were granted by the West of Scotland Research Ethics Service and Caldicott Guardian. A data collection tool was developed and piloted using a sample of 50 patients and amended following peer discussion.

In total 335 patients were identified using the Scottish Care Information - Diabetes Collaborative (SCI-DC) database. Further retrospective review of electronic medical notes via SCI-DC and the NHS Greater Glasgow and Clyde clinical portal was performed to assess eligibility for inclusion. Patients were excluded if they had been commenced on a DPP4i in primary care without a direct recommendation from a diabetes specialist.

A retrospective review of electronic patient notes was performed for eligible patients using the data collection tool. Baseline characteristics were recorded from initiation of DPP4i including concomitant antidiabetic medications, $\mathrm{HbA}_{1 c}$, weight and eGFR. The latter three measurements were then rechecked at the point of first clinic review of DPP4i therapy, at least three months after initiation.

$\mathrm{HbA}_{1 \mathrm{c}}$ and weight at initiation and review were compared separately by calculation of median change, interquartile range and $95 \%$ confidence intervals. Due to non-normal distribution of results, a Wilcoxon signed rank test was performed. A p value of $<0.05$ was used to define statistical significance.

\section{Results}

In total 264 instances of DPP4i initiation were identified between 13th March 2008 and 8th June 2012 (one patient was identified with two distinct episodes of therapy). Patient demographics and use of concomitant glucose lowering therapies are displayed in Table 1. Fifty-five patients were excluded as DPP4i therapy was initiated by a general practitioner in a primary care clinic and clinical measurements were not available. Seventeen patients were
Table 2 Frequency of initiation of individual DPP4i.

\begin{tabular}{|c|c|c|c|c|c|}
\hline \multicolumn{3}{|l|}{ Drug/Dose } & \multicolumn{3}{|c|}{ Total $n=264(\%)$} \\
\hline \multicolumn{3}{|c|}{ Linagliptin $5 \mathrm{mg}$ od } & \multicolumn{3}{|l|}{$1(0.4)$} \\
\hline \multicolumn{3}{|c|}{ Saxagliptin $2.5 \mathrm{mg}$ od } & \multicolumn{3}{|l|}{$11(4.2)$} \\
\hline \multicolumn{3}{|c|}{ Saxagliptin 5mg od } & \multicolumn{3}{|l|}{$7(2.7)$} \\
\hline \multicolumn{3}{|c|}{ Sitagliptin $25 \mathrm{mg}$ od } & \multicolumn{3}{|l|}{0} \\
\hline \multicolumn{3}{|c|}{ Sitagliptin 50mg od } & \multicolumn{3}{|l|}{$4(1.5)$} \\
\hline \multicolumn{3}{|c|}{ Sitagliptin $100 \mathrm{mg}$ od } & \multicolumn{3}{|l|}{$239(90.5)$} \\
\hline \multicolumn{3}{|c|}{ Vildagliptin $50 \mathrm{mg}$ od } & \multicolumn{3}{|l|}{0} \\
\hline \multicolumn{3}{|c|}{ Vildagliptin 50mg bd } & \multicolumn{3}{|l|}{$2(0.8)$} \\
\hline & $\begin{array}{l}\text { Patients } \\
\text { included } \\
n=264(\%)\end{array}$ & $\begin{array}{l}\text { Median } \\
\mathrm{HbA}_{1 \mathrm{c}} \\
\text { (mmol/mol) } \\
\text { (IQR) }\end{array}$ & $\begin{array}{l}\text { Median } \\
\text { change in } \\
\mathrm{HbA}_{1 \mathrm{c}} \\
(\mathrm{mmol} / \mathrm{mol})\end{array}$ & $\mathrm{Cl}$ & $\begin{array}{l}P \\
\text { value }\end{array}$ \\
\hline $\begin{array}{l}\mathrm{HbA}_{1 c} \text { at } \\
\text { initiation }\end{array}$ & $263(99.6)$ & $73(65-83)$ & & & \\
\hline $\begin{array}{l}\mathrm{HbA}_{1 c} \text { at } \\
\text { follow-up } \\
\text { (all patients) }\end{array}$ & $215(81.4)$ & $64(55-78)$ & -8.5 & $-10,-6.5$ & $<0.005$ \\
\hline $\begin{array}{l}\mathrm{HbA}_{1 c} \text { at } \\
\text { follow-up } \\
\text { (DPP4i } \\
\text { addition only }\end{array}$ & $192(72.7)$ & $64(54-76)$ & -9.5 & $-12,-6.5$ & $<0.005$ \\
\hline
\end{tabular}

deceased at the time of data collection and medical records were inaccessible via the SCI-DC store. Median time between initiation of DPP4i and follow-up review was 189 days (IQR 140-239); $90.5 \%$ of patients were initiated on sitagliptin $100 \mathrm{mg}$ daily with the full range of DPP4i and doses prescribed shown in Table 2.

\section{Glycaemic response}

Median $\mathrm{HbA}_{1 \mathrm{c}}$ at initiation and at clinic review after at least three months and median change in $\mathrm{HbA}_{1 \mathrm{c}}$ are shown in Table 3. Analysis of all patients with $\mathrm{HbA}_{1 \mathrm{c}}$ measurements at initiation and follow up yielded a median reduction in $\mathrm{HbA}_{1 \mathrm{c}}$ of $8.5 \mathrm{mmol} / \mathrm{mol}(\mathrm{n}=215)$. Refining this to include patients where DPP4i initiation was the only therapeutic adjustment ("DPP4i initiation only") at the initial visit showed a median reduction of $9.5 \mathrm{mmol} / \mathrm{mol}(\mathrm{n}=192)$. Both reductions were noted to be statistically significant.

Of the 192 patients with $\mathrm{HbA}_{1 \mathrm{c}}$ results at follow-up, 149 (77.6\%) exhibited a reduction in $\mathrm{HbA}_{1 \mathrm{c}}$ between initiation and follow-up after at least three months (Table 4). One hundred and thirty-three $(69.3 \%)$ exhibited a reduction in $\mathrm{HbA}_{1 \mathrm{c}}$ of $\geq 5 \mathrm{mmol} / \mathrm{mol}$ which indicates a successful response to DPP4i therapy according to national prescribing guidance. ${ }^{3,7}$

Comparison of $\mathrm{HbA}_{1 \mathrm{c}}$ concentration at initiation and glycaemic response to DDP4i initiation, where DPP4i initiation was the only therapeutic intervention, can be seen in Figure 1. Patients in the higher groupings of initial $\mathrm{HbA}_{1 \mathrm{c}}$ appeared to have a larger glycaemic response to therapy. 
Table 4 Subsets of glycaemic response to DPP4i therapy

\begin{tabular}{lllll}
\hline $\begin{array}{l}\text { Change } \\
\text { in } \\
\mathbf{H b A}_{\mathbf{1 c}}\end{array}$ & $\begin{array}{l}\text { Reduction } \\
\text { in } \mathbf{H b A}_{\mathbf{1 c}} \\
(\geq \mathbf{5 m m o l} / \mathbf{m o l})\end{array}$ & $\begin{array}{l}\text { Reduction } \\
\text { in } \mathbf{H b A}_{\mathbf{1 c}} \\
(\leq 5 \mathrm{mmol} / \mathbf{m o l})\end{array}$ & $\begin{array}{l}\text { No } \\
\text { Response }\end{array}$ & $\begin{array}{l}\text { Increase } \\
\text { in }\end{array}$ \\
$\begin{array}{l}\text { Total } \\
\mathbf{H b A}_{\mathbf{1 c}}\end{array}$
\end{tabular}

Figure 1. Median change in $\mathrm{HbA}_{1 c}$ according to groupings of $\mathrm{HbA}_{1 \mathrm{c}}$ concentration at initiation.

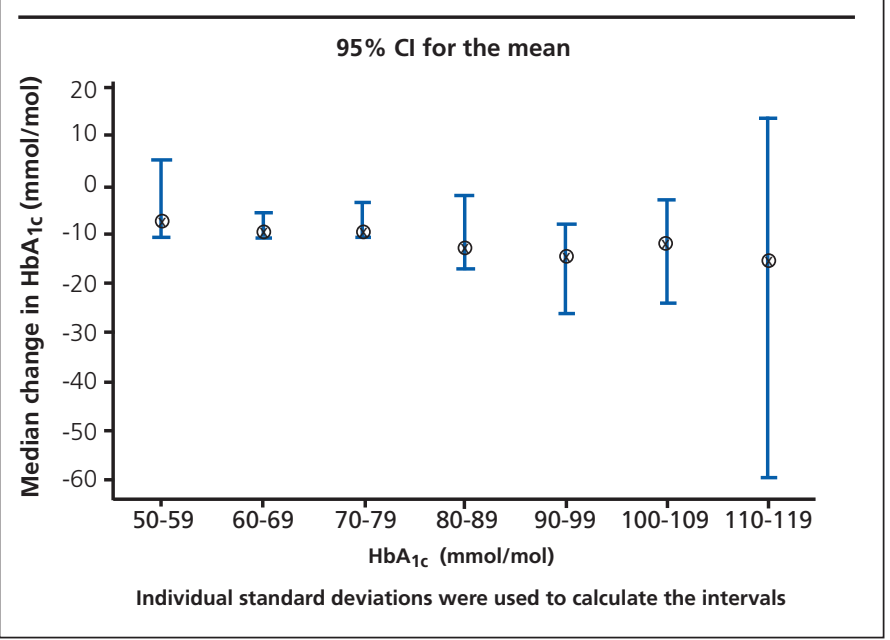

Table 5 Weight response to DPP4i therapy

\begin{tabular}{|c|c|c|c|c|c|}
\hline & $\begin{array}{l}\text { Patients } \\
\text { included } \\
n=264(\%)\end{array}$ & $\begin{array}{l}\text { Median } \\
\text { weight } \\
\text { (kg) (IQR) }\end{array}$ & $\begin{array}{l}\text { Median } \\
\text { change in } \\
\text { weight }\end{array}$ & $95 \% \mathrm{Cl}$ & $\begin{array}{l}P \\
\text { value }\end{array}$ \\
\hline $\begin{array}{l}\text { DPP4i } \\
\text { initiation }\end{array}$ & $261(98.9)$ & $\begin{array}{l}90.8 \\
(79.7-104)\end{array}$ & $\begin{array}{l}(n=181) \\
-0.45(3.35)\end{array}$ & $-1.15,-0.25$ & 0.033 \\
\hline $\begin{array}{l}\text { Clinic review } \\
\text { after at least } \\
\text { three months }\end{array}$ & 189 (72.3) & $\begin{array}{l}88.4 \\
(79.3-103)\end{array}$ & & & \\
\hline
\end{tabular}

\section{Weight response}

Change in weight between initiation and follow-up in all patients is detailed in Table 5. A small median reduction in weight was observed and was noted to be statistically significant $(p<0.05)$.

\section{Dose adjustment in renal impairment}

Two hundred and sixty patients at initiation and 193 patients at follow-up had eGFR values available for assessment. Degree of renal impairment amongst the study population is shown in Table 6. Most patients had an eGFR $>50 \mathrm{ml} / \mathrm{min} / 1.73 \mathrm{~m}^{2}$ and thus would not require any dosage adjustment of any of the currently available DPP4i according to manufacturer's guidance. In patients with moderate renal impairment (eGFR 30$50 \mathrm{ml} / \mathrm{min} / 1.73 \mathrm{~m}^{2}$ ) approximately $25 \%$ at initiation and $90 \%$ at review were prescribed unlicensed doses of DPP4i. Similarly, in
Table 6 Renal function and DPP4i dose

$\begin{array}{ll}\text { Total at initiation } & \text { Total at follow-up } \\ \text { (Total [\%] prescribed } & \text { (Total [\%] prescribed } \\ \text { licensed dose*) } & \text { licensed dose*) } \\ \mathbf{n}=\mathbf{2 6 0} & \mathrm{n}=193\end{array}$

eGFR

$\begin{array}{lll}>50 \mathrm{ml} / \mathrm{min} / 1.73 \mathrm{~m}^{2} & 217(215[99.1]) & 155(155[100]) \\ 30-50 \mathrm{ml} / \mathrm{min} / 1.73 \mathrm{~m}^{2} & 35(9[25.7]) & 28(3[10.7]) \\ 15-30 \mathrm{ml} / \mathrm{min} / 1.73 \mathrm{~m}^{2} & 8(4[50]) & 10(4[40]) \\ <15 \mathrm{ml} / \mathrm{min} / 1.73 \mathrm{~m}^{2} & 0 & 0\end{array}$

*Licensed dose in accordance with manufacturer's SPC.8-11

patients with severe renal impairment (eGFR 15-30ml/ $\left.\min / 1.73 m^{2}\right) 50 \%$ at initiation and $60 \%$ at review were prescribed unlicensed doses.

\section{Discussion}

\section{Glycaemic control}

In our study, patients with type 2 diabetes mellitus treated with DPP4i had significantly lower $\mathrm{HbA}_{1 \mathrm{c}}$ levels after at least three months. This is consistent with results observed in clinical trials. $^{3-6}$ When all patients were included there was a significant reduction in $\mathrm{HbA}_{1}$, and this may have been a greater reduction had some of this group not had other medication stopped at the same time. A significant reduction in $\mathrm{HbA}_{1 \mathrm{c}}$ was also observed in patients where addition of DPP4i was the only therapeutic intervention at initiation. This confirmation of real world glycaemic lowering efficacy of the class is reassuring. Patients with higher initial $\mathrm{HbA}_{1 \mathrm{c}}$ seem to have a greater glycaemic response.

\section{Effect on weight}

A small reduction in weight was observed amongst the patient population studied. An increase in weight of $1 \mathrm{~kg}$ has been said to confer a $2 \%$ increase in risk of disease progression in early type 2 diabetes. ${ }^{12}$ Glucose lowering therapy conferring weight neutrality or reduction is therefore likely to be beneficial in the management of type 2 diabetes, especially when compared to alternatives such as thiazolidinediones or sulphonylureas, well known to cause weight gain.

\section{Dose adjustment in renal impairment}

Adjustment of DPP4i dose for renal impairment was infrequent, suggesting a lack of prescriber awareness of recommendations for prescribing in patients with renal impairment. Exposure to sitagliptin and saxagliptin increases proportionately with reducing renal function but has not been associated with an increased incidence of adverse effects. ${ }^{13,14}$ Use of doses outwith the product licence also has potential medicolegal implications for prescribers. In a patient population where renal function tends to decline, prescribers should be aware of the potential risks 


\title{
Key messages
}

- In the 'real life' clinical setting DPP4i:

- reduce $\mathrm{HbA}_{1 c}$ similarly to randomised controlled trials

- have no effect or marginally reduce weight

- There is inadequate awareness of the need for dose adjustments of DPP4i in impaired renal function

involved in failing to adjust the dose. These results have prompted a review of clinical governance practices surrounding the use of DPP4i with a clearer focus on evaluation of renal function and drug selection or dosage adjustment.

National guidelines recommend that DPP4i be discontinued if patients fail to achieve at least a $5.5 \mathrm{mmol} / \mathrm{mol}$ reduction in $\mathrm{HbA}{ }_{1 c}$. As results from the local laboratory were not reported as decimals it was not possible to detect changes with such precision, so a lower reduction of $5 \mathrm{mmol} / \mathrm{mol}$ was used. Therefore the reported patients achieving this goal in glycaemic control may not fully reflect guidelines recommendations.

Ultimately, our experience shows that DPP4i are effective in reducing $\mathrm{HbA}_{1 c}$ and body weight in routine specialist secondary care. Inappropriate prescribing in $70 \%$ of patients with eGFR $<50 \mathrm{ml} / \mathrm{min} / 1.73 \mathrm{~m}^{2}$ indicates that there should be a review of prescribing practice.

Conflict of interest ALB has received travel grants from Boehringer Ingelheim and speakers fees from Eli Lilly. GCJ has contributed to advisory boards, received travel grants and speakers fees from Boehringer Ingelheim/Lilly/MSD/Bristol Meyers-Squibb.

Funding None.

\section{References}

1. Karagiannis T, Paschos P, Paletas K, Matthews D, Tsapas A. Dipeptidyl peptidase-4 inhibitors for treatment of type 2 diabetes mellitus in the clinical setting: systematic review and meta-analysis. BMJ 2012; 344:e1369. http://dx.doi.org/10.1136/bmj.e1369

2. Kim W, Egan J. The Role of Incretins in Glucose Homeostasis and Diabetes Treatment. Pharmacol Rev 2008;60:470-512.

http://dx.doi.org/10.1124/pr.108.000604

3. Scottish Intercollegiate Guidelines Network. Guideline 116: Management of Diabetes- A National Clinical Guideline. March 2010. www.sign.ac.uk

4. National Institute for Health and Clinical Excellence. Clinical Guideline 87: Type 2 Diabetes -The Management of Type 2 Diabetes. May 2009 www.nice.org.uk

5. Fang $\mathrm{V}$, Wazny LD, Raymond CB. Hypoglycaemics for the Treatment of Type 2 Diabetes in Patients With Chronic Kidney Disease: A Focus on New Agents. The CANNT Journal 2012;22:30-6.

6. Madsbad S, Krarup T, Deacon CF, et al. Glucagon-Like Peptide Receptor Agonists and Dipeptidyl Peptidase-4 Inhibitors in the Treatment of Diabetes: A Review of Clinical Trials. Curr Opin Clin Nutr Metab Care 2008;11:491-9. http://dx.doi.org/10.1097/ MCO.0b013e328302f414

7. Scheen AJ. DPP-4 Inhibitors in the Management of Type 2 Diabetes: A Critical Review of Head-to-Head Trials. Diabetes Metab 2012;38:89101. http://dx.doi.org/10.1016/j.diabet.2011.11.001

8. Novartis Pharmaceuticals UK Ltd. Summary of Product Characteristics: Galvus $^{\circledR}$ 50mg Tablets. Updated 21/8/12. Accessed via www.emc.medicines.org.uk

9. Merck, Sharpe and Dohme Ltd. Summary of Product Characteristics: Januvia ${ }^{\circledR} 25 \mathrm{mg}, 50 \mathrm{mg}, 100 \mathrm{mg}$ Tablets. Updated 17/09/12. Accessed via www.emc.medicines.org.uk

10. Bristol Meyers Squibb-AstraZeneca EEIG. Summary of Product Characteristics: Onglyza ${ }^{\circledR} 2,5 \mathrm{mg}$ and $5 \mathrm{mg}$ Tablets. Updated 11/1/12. Accessed via www.emc.medicines.org.uk

11. Boehring Ingelheim Ltd. Summary of Product Characteristics: Trajenta ${ }^{\circledR} 5 \mathrm{mg}$ Tablets. Updated 21/09/11. Accessed via www.emc. medicines.org.uk

12. Pani LN, Nathan DM, Grant RW. Clinical Predictors of Disease Progression and Medication Initiation in Untreated Patients with Type 2 Diabetes with A1c Less than 7\%. Diabetes Care 2008:31:386-90. http://dx.doi.org/10.2337/dc07-1934

13. Bergman AJ, Cote J, Yi B, et al. Effect of Renal Insufficiency on the Pharmacokinetics of Sitagliptin - A Dipeptidyl Peptidase 4 Inhibitor. Diabetes Care 2007;30:1862-4. http://dx.doi.org/10.2337/dc06-2545

14. Boulton DW, Li L, Frevert EU, et al. Influence of Renal or Hepatic Impairment on the Pharmacokinetics of Saxagliptin. Clin Pharmacokinet 2011; 50:25365. http://dx.doi.org/10.2165/11584350-000000000-00000

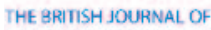 \\ Diabetes \\ $\widehat{A B C D}$ \\ Vascular Disease}

The Journal of the Association of British Clinical Diabetologists

\section{Sign up for your free subscription*}

\author{
To receive eTOC\# alerts and free issues of $\mathrm{Br} J$ Diabetes Vasc Dis please \\ click on the QR code below, or go to \\ http://bjdvd.co.uk/index.php/bjdvd/user/register, \\ or register via www.bjdvd.com
}

\begin{abstract}
*subject to meeting with our terms of control for a free copy \#electronic Table of Contents You can unsubscribe from eTOC alerts and journal receipt at any time
\end{abstract}

